F. Reprod. Fert. (1974) 37, 367-372

\title{
PLASMA PROGESTERONE BEFORE AND AFTER OVARIECTOMY IN UNMATED AND PREGNANT MINK, MUSTELA VISON
}

\author{
O. M. MØLLER \\ Department of Reproductive Physiology and Pathology, \\ Veterinary College of Norway, Norway*
}

(Received 15th May 1973)

\begin{abstract}
Summary. Five parous mink bitches remained unmated and unstimulated, during the mating season (i.e. March) and up to 17th April. Seven blood samples were taken between the 17th April and 23rd May. Two of the animals were ovariectomized on 17th April. The plasma progesterone levels and the ovarian histology indicated that unmated mink may develop active corpora lutea, presumably after spontaneous ovulation.

Six pregnant mink were ovariectomized at various stages of pregnancy. In all the bitches, the ovariectomy resulted in an abrupt fall in the peripheral plasma progesterone levels and termination of pregnancy. It seems reasonable, therefore, to assume that in the mink an obligatory relationship exists between luteal function and the maintenance of pregnancy.
\end{abstract}

\section{INTRODUCTION}

It has been stated that ovulation in the mink is dependent on mating or on analogous stimuli. Adequate stimulation may be copulation, a struggle with another animal, or mechanical stimulation of the vagina or cervix (Hansson, 1947; Enders, 1952). According to these investigations, rather strong stimulation seems to be necessary before ovulation is induced. Venge (1959), however, has claimed that many females may ovulate without any stimulation and that after such spontaneous ovulation many corpora lutea can form.

The observations reported here are consistent with the concept that unmated mink bitches may ovulate and develop functional corpora lutea, while others fail to ovulate.

The effect of spaying on the plasma progesterone levels in pregnant mink was studied. Previous observations that ovariectomy leads to the termination of pregnancy have given credence to the assumption that in this species an obligatory relationship exists between ovarian function and the maintenance of pregnancy (Enders, 1952). The present study showed that ovariectomy at various stages of pregnancy resulted in an abrupt fall in the peripheral plasma progesterone and all fetuses seemed to be resorbed or aborted.

* Postal address: Postbox 8146, Oslo-Dep., Norway. 


\section{MATERIALS AND METHODS}

Five parous mink bitches (standard type), which were used to obtain data on luteal function in unmated mink, were kept with the other females in one end of a shed from which males were excluded. The disturbance experienced by these five bitches during the mating season (i.e. March) and to 17th April, was only visual and auditory, and there was no handling of the animals during this period. On 17th April, blood samples were taken from all these bitches. At that time, and after the blood sampling, two of the animals were ovariectomized. The ovaries were fixed in $3 \%$ glutaraldehyde buffer, embedded in paraffin wax, sectioned, and finally stained with haematoxylin and eosin. After 17th April, blood samples were obtained from all the bitches until 23rd May (see Text-fig. 1).

Eight parous bitches (standard type) were used to obtain data for progesterone levels following ovariectomy at various stages of pregnancy. All these bitches were mated twice (on 2 consecutive days) during the period from 8 th to 11 th March. The sampling of blood was started within 2 days after mating, and a blood sample was collected once a week throughout the study. Blood samples were always taken immediately before ovariectomy and about $20 \mathrm{hr}$ after the operation in all the bitches. All the bitches proved to be pregnant. In three animals, the ovaries were removed at 29 days post coitum (p.c.) and three others were spayed at Day 43 p.c. In order to evaluate fetal survival after the surgical procedure, two bitches were subjected to laparotomy but not to ovariectomy. The surgical procedures were carried out under pentobarbitone sodium (Nembutal, Abbott Laboratories, 25 to $30 \mathrm{mg} / \mathrm{kg}$ intrapulmonary) anaesthesia.

All the blood samples were taken between 09.00 and 10.00 hours, and were handled as described previously (Møller, 1973a). Duplicate measurements of progesterone on $0 \cdot 2-\mathrm{ml}$ plasma samples were performed by a rapid competitive protein-binding technique described by Johansson (1969) with minor modifications (Fylling, 1970). The routine work was carried out exactly as in the procedures used by Møller (1973a). For the entire procedure, the coefficient of variations (between assays) was $11.3 \%$ between 1.25 and $5 \mathrm{ng}, 8.7 \%$ between 5 and $10 \mathrm{ng}$ and $12.3 \%$ between 10 and $20 \mathrm{ng}$ on the standard curve. The recovery was $92 \cdot 8 \pm 4.0 \%$ (S.D.).

\section{RESULTS}

\section{Influence of ovariectomy on the plasma progesterone in the unmated mink}

Text-figure 1(a) shows the progesterone profiles which were obtained from the two unmated, ovariectomized bitches. Immediately before ovariectomy, the plasma progesterone levels differed clearly between these animals, e.g. 27 $\mathrm{ng} / \mathrm{ml}$ in No. 94 and $9 \mathrm{ng} / \mathrm{ml}$ in No. 22. A plausible explanation for this difference was provided by histological examination of the ovaries. Both ovaries obtained from No. 94 contained many well-developed corpora lutea (Pl. 1, Figs 1 and 2). No ova, or remnants of ova, could be found within the corpora lutea from No. 94, even though serial sections throughout the ovaries were examined. This indicates that No. 94 had ovulated spontaneously. By contrast, 
the ovaries obtained from No. 22 contained no corpora lutea, but many large follicles. The granulosa layer in these large follicles showed an incipient luteinization even though the ova were still present (Pl. 1, Figs 3 and 4).

Text-figure 1(b) shows the progesterone profiles in the three bitches that were unmated and remained intact during the period between 17th April and 23rd May.

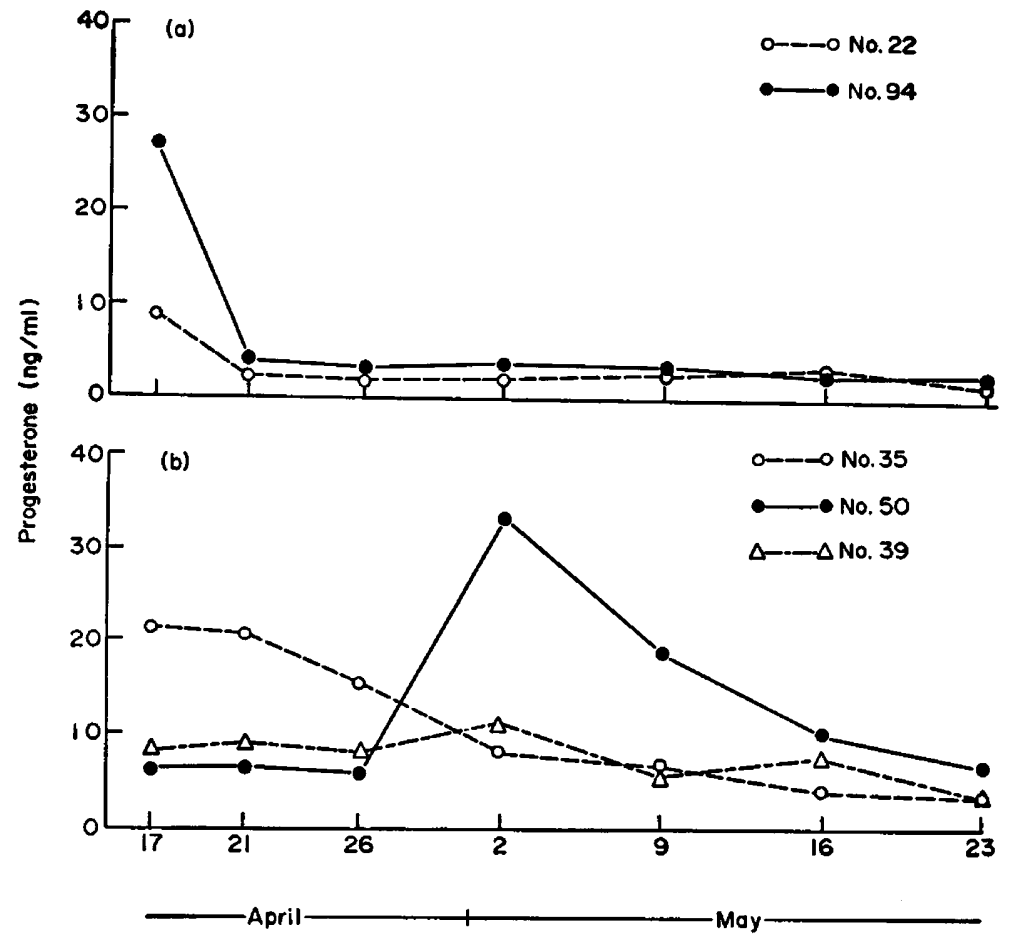

Text-Fig. 1. Plasma progesterone concentrations during the period from 17th April to 23rd May in unmated mink bitches: (a) two bitches which were ovariectomized immediately after removal of blood samples on 17th April; (b) three bitches which remained intact throughout the study.

\section{Infuence of ovariectomy at different stages of pregnancy on plasma progesterone levels}

Text-figure 2(a) shows the progesterone profiles obtained from three bitches which were ovariectomized on Day 29 p.c. In the samples which were taken immediately before ovariectomy the plasma progesterone levels were 58, 76 and $84 \mathrm{ng} / \mathrm{ml}$, respectively. In all these bitches, ovariectomy resulted in a fall in the peripheral plasma progesterone to below $10 \mathrm{mg} / \mathrm{ml}$ measured about $20 \mathrm{hr}$ later. A week after surgery, the plasma progesterone concentrations corresponded with those observed in anoestrous mink, i.e. $<4 \mathrm{ng} / \mathrm{ml}$ in the assay system used. None of the bitches that were ovariectomized at Day 29 p.c. showed signs of abortion or delivery. It seems likely, therefore, that in these bitches all the fetuses died and were resorbed.

Text-figure 2(b) shows the progesterone profiles obtained from the three bitches which were ovariectomized on Day 43 p.c. Even in these bitches, the 
plasma progesterone fell significantly after ovariectomy. Bitch No. 77 expelled four nearly mature but dead fetuses on the 4th day after the ovaries were removed. In the other two bitches (No. 69 and No. 12), no signs of abortion were noticed, and no cubs were born. It seems apparent that no fetuses survived.

Text-figure 2(c) shows the progesterone profiles obtained from the two bitches which were subjected to laparotomy without removal of the ovaries. The progesterone values and profiles obtained throughout pregnancy in these
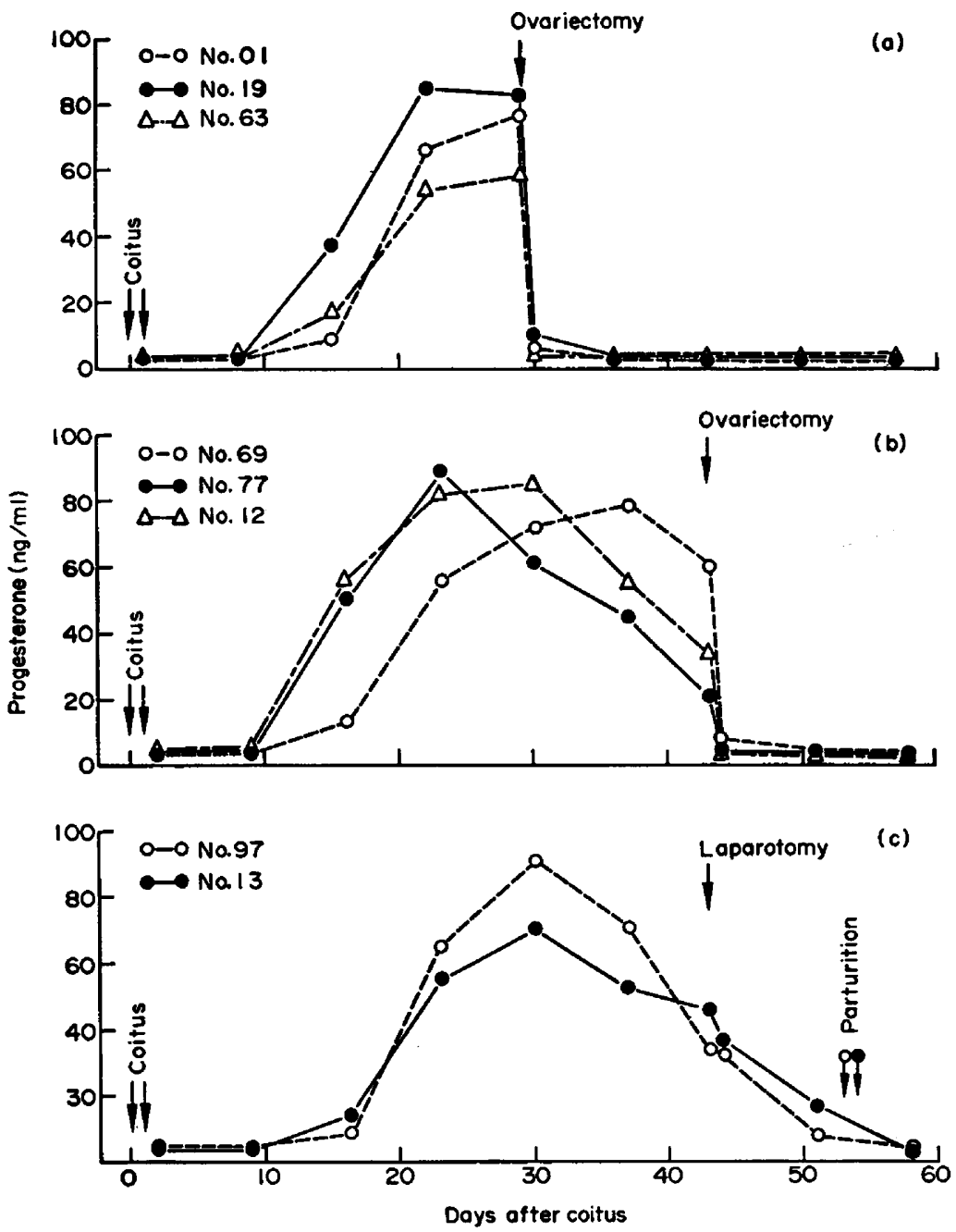

TExT-FIG. 2. Plasma progesterone concentrations before and after ovariectomy in six pregnant mink ( $a, b)$, and before and after laparotomy in two pregnant mink (c): (a) three bitches which were ovariectomized on Day 29 post coitum (p.c.). None of these bitches expelled fetuses at any time afterwards: (b) three bitches which were ovariectomized on Day 43 p.c. No. 77 expelled four dead fetuses on the 4th day after ovariectomy. In the other two bitches (No. 69 and No. 12), no signs of abortion or delivery were recognized after the removal of the ovaries: (c) two bitches which were subjected to laparotomy on Day 43 p.c. without removal of the ovaries. No. 97 gave birth to five young on Day 53 p.c. and No. 13 gave birth to four young on Day 54 p.c. 


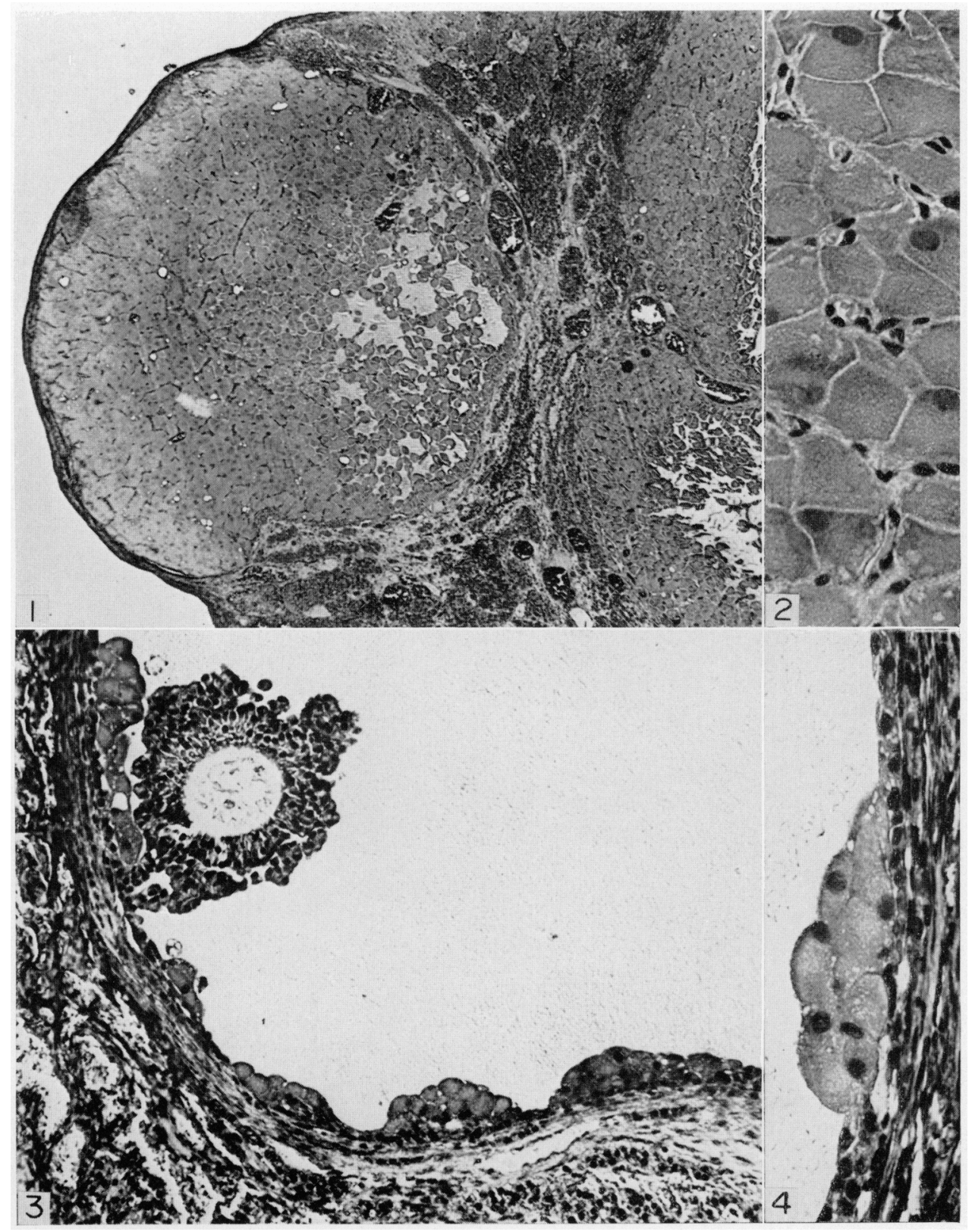

Fici. 1. Photomicrograph of an ovarian section obtained from mink No. 9t (cf. T'ext-fig. 1a). Note the well developed corpora lutea. H \& E. $\times 36$.

Fig. 2. Iutein cells from a corpus lutcum from mink No. 94 (c. Fig. 1). H \& E. $\times 415$, Fig. 3. Photomicrograph of ovarian section obtained from mink No. 22 (cf. Text-fig. la). Note the incipient luteinization of the follicle and the presence of the ovum. $\mathrm{H} \& \mathrm{~F}$. $\times 150$.

Fic. 4. Partial luteinization of the granulosa laver in an unovulated follicle obtained from mink No. 22 (cf. Fig. 3). H \& F. $\times 415$.

(Facing p. 370) 
females corresponded clearly with those observed in pregnant mink in a previous study (Møller, 1973a). Both of these intact bitches delivered mature fetuses 53 and 54 days p.c.

\section{DISGUSSION}

Ovarian luteal function in the unmated mink

The present findings suggest that unmated (i.e. unstimulated) mink may ovulate spontaneously, and develop functional corpora lutea. The maximum plasma progesterone levels in Nos. 94, 35 and 50 correspond clearly with the maximum levels obtained from mated females which failed to give birth to young (Møller, 1973a). On the other hand, it appears reasonable to assume that many unmated mink fail to ovulate during the breeding season. In bitch No. 39, the plasma progesterone levels remained only slightly above the basal level (i.e. $<4 \mathrm{ng} / \mathrm{ml}$ ) throughout the study. This probably indicates that no corpora lutea were developed in this female. Unovulated follicles with incipient luteinization, as in bitch No. 22 (Pl. 1, Figs 3 and 4), may have been responsible for the small but measurable amounts of progesterone in bitch No. 39. The abundant ovarian interstitial gland may also be a source of progesterone (Møller, $1973 b, c)$.

In the light of the data obtained from mink No. 94 (see Pl. 1, Figs 1 and 2, Text-fig. 1a), it seems reasonable to suggest that No. 35 had developed corpora lutea when the blood sampling was started. The gradual decline in the plasma progesterone to a basal level on 23rd May probably indicates a slow regression of luteal tissue.

In bitch No. 50, the plasma progesterone concentration was observed to be slightly above the, basal level on 17 th April, e.g. $6 \mathrm{ng} / \mathrm{ml}$. However, 15 days later, the level was $33 \mathrm{ng} / \mathrm{ml}$ (Text-fig. 1b). This profile may be explained as follows: on 17th April, the ovaries contained unovulated follicles with incipient luteinization of the granulosa cells (Pl. 1, Figs 3 and 4). Furthermore, owing to the handling of the animals, the follicles may have ovulated thus allowing the corpora lutea to be formed. According to recent data about the interaction between oocytes and follicular cells (Nalbandov, 1972), it is possible that in the mink the oocytes have some ability to inhibit follicular luteinization. Luteinization might also occur without ovulation because of the death of the ovum as suggested by the work of El-Fouly, Cook, Nekola \& Nalbandov (1970) on the rabbit.

\section{Influence of ovariectomy and plasma progesterone levels in pregnant mink}

In all the bitches which were pregnant, ovariectomy resulted in an abrupt fall in the plasma progesterone levels and all fetuses seemed to be resorbed or aborted. The observation that ovariectomy led to the termination of pregnancy in the mink was consistent with previous observations (Enders, 1952). Knowledge concerning the essential rôle of progesterone in pregnancy (Bedford, Challis, Harrison \& Heap, 1972) together with the present result, makes it seem probable that in the mink an obligatory relationship exists between luteal function and the maintenance of pregnancy. To confirm the assumption, 
however, it must be proved that pregnancy can be maintained after ovariectomy by the administration of progesterone.

From the present findings, it is apparent that the placental production of progesterone is insufficient to maintain the pregnant state in the mink. Consideration should be given to the existence of a supplementary placental source of progesterone, which may be similar to that observed in the rat (Csapo \& Wiest, 1969).

The present observations are consistent with a previous concept that in this species the corpora lutea are presumably the main sites of the release of progesterone during pregnancy even though the ovarian interstitial tissue may be a contributory source (Møller, 1973b, c).

\section{REFERENCES}

Bedford, G. A., Ghallis, J. R. G., Harrison, F. A. \& Heap, R. B. (1972) The rôle of oestrogens and progesterone in the onset of parturition in various species. $\mathcal{7}$. Reprod. Fert., Suppl. 16, 1.

Csapo, A. I. \& WIEsT, W. G. (1969) An examination of the quantitative relationship between progesterone and the maintenance of pregnancy. Endocrinology, 85, 735.

El-Fouly, M. A., Cook, B., Nekola, M. \& Nalbandov, A. V. (1970) Role of the ovum in follicular luteinization. Endocrinology, 87, 288.

Enders, R. K. (1952) Reproduction in the mink (Mustela vison). Proc. Am. phil. Soc. 96, 691.

Hansson, A. (1947) The physiology of reproduction in mink (Mustela vison, Schreb) with special reference to delayed implantation. Acta zool., Stockh. 28, 1.

Fylling, P. (1970) The effect of pregnancy, ovariectomy and parturition on plasma progesterone level in sheep. Acta endocr., Copenh. 65, 273.

Johansson, E. D. B. (1969) Progesterone levels in peripheral plasma during the luteal phase of the normal human menstrual cycle measured by a rapid competitive protein binding technique. Acta endocr., Copenh. 61, 592.

Møller, O. M. (1973a) The progesterone concentrations in the peripheral plasma of the mink (Mustela vison) during pregnancy. $\mathcal{F}$. Endocr. 56, 121.

MøLlER, O. M. (1973b) The fine structure of the lutein cells in the mink (Mustela vison) with special reference to the secretory activity during pregnancy. Z. Zellforsch. mikrosk. Anat. 138, 523.

Maller, O. M. (1973c) The fine structure of the ovarian interstitial gland cells in the mink (Mustela vison). 7. Reprod. Fert. 34, 171.

Nalbandov, A. V. (1972) Interaction between oocytes and follicular cells. In Oogenesis. Eds. J. D. Biggers and A. W. Schuetz. University Park Press, Baltimore.

Venge, O. (1959) Reproduction in the fox and mink. Anim. Breed Abstr. 27, 129. 